\title{
Полякова М.Д. \\ Современные технологии обучения иностранному языку в профессиональном образовании
}

\section{Аннотация}

Статья посвящена проблеме оптимизации учебного процесса, повышения эффективности обучения иностранному языку, применению современных технологий и методик обучения в профессиональном образовании. Определяется понятие технологии обучения, приводятся показатели её эффективности. Приводятся факторы и условия, влияющие на эффективную организацию образовательного процесса, интенсификацию обучения и формирование необходимых компетенций.

Ключевые слова: иностранный язык, технологии обучения, оптимизация обучения, профессиональное образование.

\section{Abstract}

The article is devoted to the problem of educational process optimization, increasing the effectiveness of teaching a foreign language, applying modern technologies and teaching methods in professional education. It gives a definition of the concept of teaching technology, indicators of its effectiveness. The author points out factors and conditions that affect the effective organization of the educational process, the intensification of training and the formation of the necessary competences.

Keywords: foreign language, teaching technologies, educational process optimization, professional education.

Современный технический прогресс заставляет образование меняться, оно становиться все более гибким и мобильным, технологии обучения совершенствуются, а достигаемый результат ориентируется на потребности рынка труда.

Современные технологии обучения нацелены на оптимизацию процесса обучения, в их основе находятся такие важные показатели, как результативность, экономичность, эргономичность и мотивированность. Для обеспечения результативности обучения необходим высокий уровень достижения поставленной учебной цели каждым учащимся. Под экономичностью подразумевается усвоение большого количества материала за единицу времени при наименьшей затрате усилий на овладение материалом. Эргономичность означает, что обучение должно происходить в обстановке положительного эмоционального микроклимата, при отсутствии значительного переутомления и перегрузки, в атмосфере сотрудничества. Высокая мотивированность необходима для повышения интереса к занятиям и позволяет совершенствовать лучшие личностные качества обучаемого, раскрывает его резервные возможности [1, с. 78$]$.

На основе проведенного анализа нам удалось обозначить следующие проблемы:

- «глобальность» заявленных общекультурных и профессиональных компетенций для бакалавров неязыковых направлений подготовки и несоответствующее для их формирования количество аудиторных часов;

— низкий пороговый уровень языковой подготовки обучающихся;

— большой разброс уровней подготовки между первокурсниками, закончившими сельские, городские или специализированные школы, училища; 
- критически низкий уровень ответственности студентов за результаты овладения иностранным языком;

- отсутствие навыков самостоятельной деятельности к образовательному процессу и творческого подхода к процессу обучения иностранному языку.

Анализ выявленных проблем позволил обнаружить наиболее эффективные и оптимальные подходы и технологии для организации обучения иностранному языку студентов неязыковых направлений бакалавриата и магистратуры в условиях реализации федеральных государственных образовательных стандартов высшего образования в университете.

На наш взгляд, наиболее перспективной технологией успешной организации образовательного процесса представляется технология модульного обучения иностранному языку. Данная методика позволяет решить вопросы, связанные с эффективной организацией и оптимизацией самостоятельной работы студентов в процессе изучения иностранного языка, а это, в свою очередь, повышает уровень иноязычной подготовки будущего специалиста, но и качество его профессиональной подготовки.

Считаем целесообразным отметить следующие преимущества технологии модульного обучения:

— возможность многоуровневой иноязычной подготовки студентов;

— четкое структурирование содержания обучения;

- гибкость предоставления учебного материала для самостоятельной работы обучающихся в процессе изучения иностранного языка;

— накопительный принцип оценивания работы студента;

— гибкий график усвоения нового содержания в рамках освоения учебного материала по изучаемой дисциплине;

- приспособление дидактической системы к индивидуальным возможностям и уровню базовой иноязычной подготовки будущих бакалавров в процессе организации самостоятельной работы по индивидуальной учебной программе [2, с. 187].

Использование технологии модульного обучения иностранному языку в образовательном процессе предполагает учет принципов модульного обучения:

1. Принцип модульности, требующий представление учебного материала законченным блоком-модулем;

2. Принцип динамичности, который позволяет видоизменить содержание обучения в зависимости от уровня языковой подготовки студента, формы организации учебно-познавательной деятельности с позиции адаптивности, комфортности обучающегося;

3. Принцип системности знаний, который предусматривает вариативность обучения, разнообразие его форм и методов, а также формирование общеучебных умений и навыков;

4. Принцип успешности предусматривает использование стимулирующего поощрения учебно-познавательной деятельности студента посредством применения фонда оценочных средств по дисциплине «Иностранный язык».

Дистанционная технология обучения иностранному языку предполагает организацию учебного процесса, который предусматривает обучение на расстоянии с использованием компьютерных телекоммуникационных сетей. Главной особенностью технологии дистанционного обучения является опосредованный характер общения. В настоящее время разработаны различные варианты организации дистанционного обучения иностранным языкам [1, с. 114]. Эффективность подобного рода технологий заключается в их способности подстраиваться под обучающегося. Индивидуальный 
подход и выстроенные в соответствии с ним учебные траектории являются гарантией лучшего результата.

В последнее время преподаватели иностранного языка все чаще сталкиваются с понятием «выученной беспомощности». Выученная беспомощность наблюдается в том случае, когда в процессе изучения иностранного языка задание кажется студенту настолько трудным, что начинаются сомнения в своей способности найти правильное решение. Выученная беспомощность - это психологическое состояние, которое связано с мотивацией деятельности. Обучающиеся с внешней учебной мотивацией, сталкиваясь с временными трудностями, испытывают чувство беспомощности и снижают активность. Студенты же с внутренней мотивацией более устойчивы к временным непреодолимым трудностям, при столкновении с трудностями не снижают уровень активности. Задача преподавателя - создать высокую внутреннюю мотивацию в процессе обучения иностранному языку.

В данной ситуации считаем целесообразным применение технологии «Scaffolding». В переводе с англ. scaffolding - строительные леса. Учебный скаффолдинг - процесс, который дает возможность обучающемуся решить проблему. Учебные «леса», это различного вида временные опоры, которые являются необходимой поддержкой обучающихся, помогающими каждому достичь поставленных целей. По мере продвижения обучающихся эти опоры постепенно убираются.

Суть технологии заключается в следующем: преподаватель с помощью специальных познавательных или проблемно-поисковых заданий и инструкций направляет обучающегося к открытию нового знания, опираясь на имеющийся у него опыт. Данная технология рассматривается как особый тип процесса инструктирования, которая имеет место в ситуациях взаимодействия педагога и обучающихся по решению учебных задач. Основной характеристикой стратегии «scaffolding» является «угасающая помощь» (fading help) со стороны преподавателя, т.е. уменьшение степени интенсивности оказания помощи до момента, когда студент становится совершенно самостоятельным и автономным [3].

В качестве итога, необходимо выделить два основных способа интенсификации процесса обучения. Первый - за счет максимального использования современных технологий и технических средств, второй - за счет активизации роли каждого обучающегося в учебном процессе. Можно утверждать, что изменение структуры подачи материала, активации обучающихся, развитие технологий, интернета и различных форм дистанционного обучения наиболее перспективно в совершенствовании технологий обучения иностранному языку в ближайшие годы.

$$
* * *
$$

1. Аверьянов П.Ф. Проблемы качества образования. Успехи современного естествознания. М., ИНФА, 2015. $275 \mathrm{c}$.

2. Иванова О.Ю., Антонова Ю.Н. Технология модульного обучения иностранному языку как средство организации самостоятельной работы бакалавров// Проблемы лингвистики, методики обучения иностранным языкам и литературоведения в свете межкультурной коммуникации: сборник материалов II Международной научно-практической Интернет-конференции (27-28 февраля 2017 г.) / под ред. О.Ю. Ивановой. Орел: ФГБОУ ВО «ОГУ имени И.С. Тургенева», 2017. C. $185-189$.

3. Красавина О.И. Формирование переводческой компетенции студентов технического вуза с использованием скэффолдинга // Санкт-Петербургский государственный политехнический университет Студенты и молодые ученые - инновационной России: материалы работ молодежной научной конференции. СПб.: Изд-во Политехн. ун-та, 2013. 370 с.

4. Сафонова В.В. Изучение языков международного общения в контексте диалога культур и цивилизаций. М., ИНФА, 2015. 375 с.

5. Тимофеева Е.В. Особенности коммуникативной компетенции в обучении иноязычному общению // Язык и коммуникация в контексте культуры: материалы Второй международной научнопрактической конференции. М., ИНФА, 2015. 413 с. 